RNA 25: 1061-1077 (2019)

\title{
Corrigendum: Telomeric small RNAs in the genus Caenorhabditis
}

STEPHEN FRENK, EVAN H. LISTER-SHIMAUCHI, and SHAWN AHMED

Supplemental Material for the above-noted paper should have included these elements only: Supplemental File 1, nine Supplemental Tables, and one Supplemental Figure.

The lone citation to Supplemental File 2 has been removed (p.1069), the lone citation to Supplemental File 3 (p.1073) has been changed to Supplemental Table S9 instead, and Supplemental File 1, which was missing originally, is now cited on pages 1064 and 1068 and can be found in the Additional Supplemental Material link online.

The paper has been corrected online, and the authors apologize for any confusion this may have caused.

doi: $10.1261 /$ rna.072926.119 

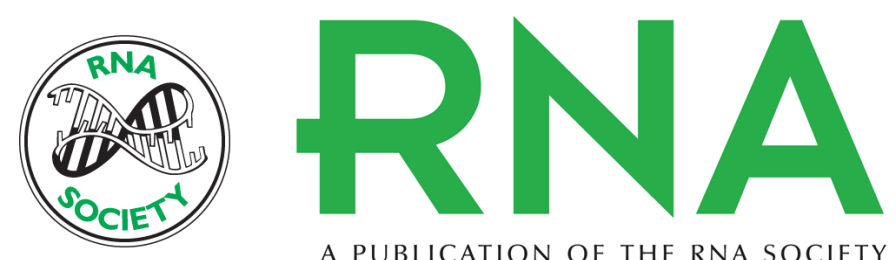

A PUBLICATION OF THE RNA SOCIETY

\section{Corrigendum: Telomeric small RNAs in the genus Caenorhabditis}

Stephen Frenk, Evan H. Lister-Shimauchi and Shawn Ahmed

RNA 2019 25: 1405

Related Content Telomeric small RNAs in the genus Caenorhabditis

Stephen Frenk, Evan H. Lister-Shimauchi and Shawn Ahmed

RNA September , 2019 25: 1061-1077

Open Access Freely available online through the RNA Open Access option.

License

Email Alerting Receive free email alerts when new articles cite this article - sign up in the box at the Service top right corner of the article or click here.

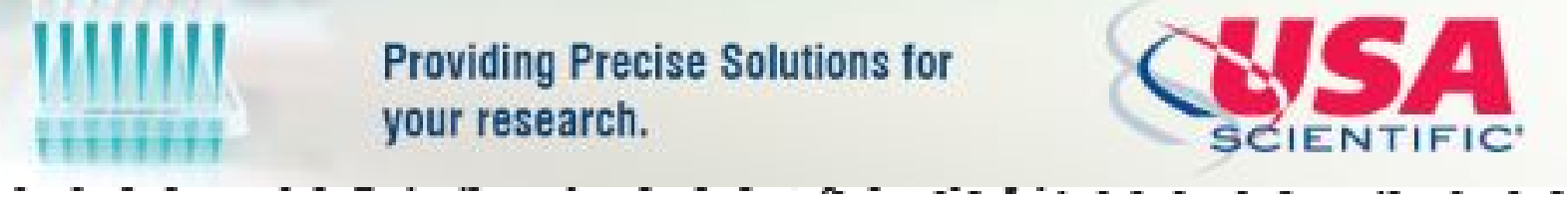

To subscribe to $R N A$ go to:

http://rnajournal.cshlp.org/subscriptions

Published by Cold Spring Harbor Laboratory Press for the RNA Society 